\title{
PENINGKATAN KEMAMPUAN BERPIKIR KRITIS SISWA DENGAN APLIKASI KAHOOT PADA MATERI TRANSFORMASI
}

\section{IMPROVEMENT OF STUDENT CRITICAL THINKING ABILITY WITH KAHOOT APPLICATION IN TRANSFORMATION MATERIAL}

\author{
Mambaul Ulum ${ }^{1}$, Nur Ida Hasnatin ${ }^{2}$, Faridatul Masruroh ${ }^{3}$ \\ ${ }^{1}$ Pendidikan Matematika, MTsN 2 Kota Kediri, Jl. Sunan Ampel 12 Ngronggo Kota Kediri, \\ 64127, Indonesia \\ 2 Pendidikan Matematika, SMA Negeri 1 Kalitidu, J1 Raya Ngasem No 458 Kalitidu, 62154, \\ Indonesia \\ 3 Pendidikan Matematika, STKIP PGRI Jombang, Jl. Patimura III/20 Jombang, 61418, Indonesia \\ ${ }^{*}$ E-mail: mambaulum123@yahoo.com
}

Hp:0816528049

\begin{abstract}
ABSTRAK
Dalam Kegiatan Belajar Mengajar (KBM) di sekolah, belum banyak guru yang mengajak siswa untuk melakukan berpikir kritis. Siswa hanya mencatat atau menyalin dan cenderung menghafal rumus-rumus atau aturan-aturan matematika dengan tanpa makna dan pengertian. Untuk mengatasi permasalahan ini perlu adanya kreativitas dan inovasi dari guru dalam proses KBM di kelas. Peneliti mencoba memberikan alternatif pengajaran untuk meningkatkan daya berpikir kritis siswa melalui pembelajaran matematika pada bab transformasi dengan menggunakan aplikasi kahoot. Aplikasi ini cukup membuat adrenalin siswa meningkat dengan menuntut kecepatan dan ketepatan dalam menjawab permasalahan yang disajikan oleh guru. Dalam penelitian yang telah dilaksanakan peneliti di MTsN 2 Kota Kediri menggunakan Penelitian Tindakan Kelas (PTK) menunjukkan bahwa terdapat peningkatan daya berpikir kritis siswa. Penelitian dilaksanakan dengan dua siklus. Pengambilan data pada penelitian ini adalah data tes kemampuan berpikir kritis dengan memakai 3 indikator berpikir kritis, yaitu (1) menentukan masalah atau isu nyata, proyek, atau keputusan yang betul-betul dipertimbangkan untuk dikritisi dengan cara menuliskan yang diketahui dan ditanyakan, (2) mencari alternatif penyelesaian dengan cara menuliskan beberapa cara penyelesaian, dan (3) membuat alasan yang mendasari dalam fakta-fakta yang meyakinkan dengan memberikan alasan pada setiap langkah penyelesaian. serta pengambilan dokumentasi. Pengambilan data sebelum adanya pemakaian media kahoot, selanjutnya pada siklus 1 dan pada siklus 2 . Hasil Penelitian Tindakan Kelas (PTK) ini menunjukkan bahwa dengan pemakaian aplikasi kahoot dapat meningkatkan kemampuan berpikir kritis siswa mulai dari sebelum pemakaian, siklus 1 dan siklus 2 dengan memakai 3 indikator berpikir kritis. Namun demikian untuk memaksimalkan hasil pembelajaran perlu pemberian motivasi kepada siswa sebelum pembelajaran serta pembagian kelompok harus sesuai kaidah Perlu penelitian lanjutan untuk indikator berpikir kritis yang lain agar semakin memantabkan media kahoot ini.
\end{abstract}

Kata kunci : Berpikir Kritis, PTK, Kahoot, 
Jurnal THEOREMS (The Original Research of Mathematics) Vol.5 No.1, Juli. hal. 13-24

URL: http://jurnal.unma.ac.id/index.php/th

Naskah masuk:2020-01-17 Naskah diperbaiki:2020-04-16 Naskah diterima:2020-04-19

ABSTRACT

In Teaching and Learning Activities in schools, there are not many teachers who invite students to do critical thinking. Students only record or copy and tend to memorize mathematical formulas or rules with no meaning and understanding. To overcome this problem there needs to be creativity and innovation from the teacher in the teaching and learning process in the classroom. Researchers try to provide alternative teaching to improve students' critical thinking through mathematics learning in the transformation chapter using the application kahoot. This application is enough to make students' adrenaline increase by demanding speed and accuracy in answering the problems presented by the teacher. In research that has been carried out researchers at MTsN 2 Kota Kediri using Classroom Action Research (CAR) showed that there was an increase in students' critical thinking power. The study was conducted in two cycles. Data retrieval in this research is critical thinking skills test data using 3 indicators of critical thinking, namely (1) determining the real problem or issue, project, or decision that is really considered to be criticized by writing down what is known and asked, (2) look for alternative solutions by writing down a number of solutions, and (3) making the underlying reasons in convincing facts by giving reasons at each step of the settlement. and documentation taking. Retrieval of data before the use of kahoot media, then in cycle 1 and cycle 2. The results of Classroom Action Research (CAR) show that by using the application kahoot can improve students' critical thinking skills starting from before usage, cycle 1 and cycle 2 using 3 indicator of critical thinking. However, to maximize learning outcomes it is necessary to provide motivation to students before learning and group division must be in accordance with the rules. Further research is needed for other critical thinking indicators to further stabilize this media.

\section{Keywords: Critical Thinking, CAR, Kahoot}




\section{PENDAHULUAN}

Dalam Kegiatan Belajar Mengajar (KBM) di sekolah, belum banyak guru yang mengajak peserta didik untuk melakukan berpikir kritis. Kondisi ini dapat dilihat ketika guru dan siswa melalui proses KBM. Guru menjelaskan apa-apa yang telah disiapkan dan memberikan soal latihan yang bersifat rutin dan prosedural. Siswa hanya mencatat atau menyalin dan cenderung menghafal rumus-rumus atau aturanaturan matematika dengan tanpa makna dan pengertian.

Kemampuan berpikir kritis sangat diperlukan oleh siswa. Karena dengan kemampuan tersebut siswa dapat menyelesaikan semua permasalahan yang dihadapinya dalam pembelajaran. Sebagaimana [1] mendefinisikan berpikir kritis adalah berpikir yang menguji, menghubungkan, dan mengevaluasi semua aspek dari situasi masalah. Termasuk di dalam berpikir kritis adalah mengelompokkan, mengorganisasikan, mengingat dan menganalisis informasi. Berpikir kritis memuat kemampuan membaca dengan pemahaman dan mengidentifikasi materi yang diperlukan dengan yang tidak ada hubungan. Hal ini juga berarti dapat menggambarkan kesimpulan dengan sempurna dari data yang diberikan, dapat menentukan ketidakkonsistenan dan kontradiksi di dalam sekelompok data. Berpikir kritis adalah analitis dan refleksif.

Secara umum berpikir kritis di asumsikan sebagai sebuah proses kognitif, sebuah aktivitas mental yang memungkinkan pengetahuan diakuisisi. Pengertian ini mengacu pada definisi para ahli yang dikutip oleh [2] bahwa berkipir kritis adalah kombinasi pemikiran-pemikiran atau manipulasi mental dari masukan sensoris untuk memformulasi pikiran, alasan, atau untuk menimbang dan berpikir kritis itu sebuah eksistensi bukti yang sesuai dengan bukti itu sendiri.

Manfaat kemampuan berpikir kritis dalam pembelajaran sangat besar peranannya dalam meningkatkan proses dan hasil belajar. Beberapa penelitian membuktikan manfaat kemampuan berpikir kritis dalam pembelajaran maupun sebagai bekal masa depan yaitu Lawson dalam [17] menyatakan bahwa menurut teori Piaget, perkembangan kemampuan penalaran formal sangat penting bagi perolehan (penguasaan) konsep, karena pengetahuan konseptual merupakan akibat atau hasil dari suatu proses konstruktif, dan kemampuan penalaran tersebut adalah alat yang diperlukan pada proses itu. Kemampuan penalaran formal merupakan kemampuan berpikir kritis. Norland dan De Vito dalam [18] menemukan adanya korelasi antara penalaran dengan hasil belajar IPA. Hasrudin dalam [17] menemukan bahwa siapa yang memiliki penalaran tertinggi (yang menggunakan pembelajaran berpola PBMP) ternyata juga memiliki hasil belajar kognitif tertinggi. [2] menemukan bahwa pembelajaran kontekstual dengan metode pembelajaran berdasarkan masalah mampu membuat siswa berkemampuan akademik rendah dan pada saat yang sama mampu membuat siswa berkemampuan akademik rendah memiliki penguasaan konsep-konsep biologi yang tidak berbeda dengan siswa berkemampuan akademik tinggi. Dari penemuan-penemuan penelitian tersebut telah menjadi bukti bahwa kemampuan berpikir kritis mempunyai manfaat yang konkrit dalam meningkatkan hasil belajar siswa.

Menurut Ennis dalam [16] ciri-ciri penting siswa yang telah memiliki watak untuk selalu berpikir kritis adalah (a) mencari pernyataan atau 
pertanyaan yang jelas artinya atau maksudnya, (b) mencari dasar atas suatu pernyataan, (c) berusaha untuk memperoleh informasi terkini, (d) menggunakan dan menyebutkan sumber yang dapat dipercaya, (e) mempertimbangkan situasi secara menyeluruh, (f) berusaha relevan dengan pokok pembicaraan, (g) berusaha mengingat pertimbangan awal atau dasar, (h) mencari alternatifalternatif, (i) bersikap terbuka, (j) mengambil posisi (atau mengubah posisi) apabila bukti-bukti dan dasardasar sudah cukup baginya untuk menentukan posisinya, (k) mencari ketepatan seteliti-telitinya, (l) berurusan dengan bagian-bagian secara berurutan hingga mencapai seluruh keseluruhan yang kompleks, (m) menggunakan kemampuan atau ketrampilan kritisnya sendiri, (n) menggunakan kemampuan berpikir kritis orang lain

Kemampuan berpikir kritis dapat ditingkatkan melalui latihan. Berikut ini diberikan delapan langkah yang dapat membantu siswa atau orang yang ingin meningkatkan kemampuannya dalam berpikir kritis, yaitu (1) menentukan masalah atau isu nyata, proyek, atau keputusan yang betul-betul dipertimbangkan untuk dikritisi, (2) menentukan poin-poin yang menjadi pandangan, (3) memberikan alasan mengapa poin-poin itu dipertimbangkan untuk dikritisi, (4) membuat asumsi-asumsi yang diperlukan, (5) bahasa yang digunakan harus jelas, (6) membuat alasan yang mendasari dalam fakta-fakta yang meyakinkan, (7) mengajukan kesimpulan, dan (8) menentukan implikasi dari kesimpulan tersebut.

Dari penjelasan di atas peneliti dalam penelitian ini mengambil indikator berpikir kritis meliputi :
1. Menentukan masalah atau isu nyata, proyek, atau keputusan yang betulbetul dipertimbangkan untuk dikritisi dengan cara menuliskan yang diketahui dan ditanyakan.

2. Mencari alternative penyelesaian dengan cara menuliskan beberapa cara penyelesaian.

3. Membuat alasan yang mendasari dalam fakta-fakta yang meyakinkan dengan memberikan alasan pada setiap langkah penyelesaian

Namun banyak siswa yang mengalami kesulitan dalam melakukan aktivitas berpikir kritis. Hal tersebut berdasarkan hasil penelitian awal di MTsN 2 Kota Kediri nampak bahwa terdapat $40 \%$ siswa yang memiliki kemampuan berpikir kritis pada indikator pertama, terdapat $20 \%$ siswa pada indikator ke dua, serta terdapat $50 \%$ siswa pada indikator ke tiga.

Gambar 1 merupakan contoh hasil penelitian awal dengan pembelajaran konvensional sebelum pemakaian media aplikasi kahoot dengan materi tranformasi. [20] menyatakan ada tiga strategi spesifik untuk pembelajaran kemampuan berpikir kritis, yakni membangun kategori, menentukan masalah, dan menciptakan lingkungan yang mendukung (fisik dan intelektual). Hal ini dikarenakan pendidikan merupakan proses sosial yang tidak dapat terjadi tanpa adanya interaksi antar siswa [21] Aktivitas belajar dan bekerja secara kooperatif dalam kelompok kecil dapat mengakomodasi perkembangan kemampuan berpikir kritis matematis.

Kemampuan berpikir kritis dapat dikembangkan melalui pembelajaran matematika di sekolah atau pun perguruan tinggi, yang menitik beratkan pada sistem, struktur, konsep, prinsip, serta kaitan yang ketat antara suatu unsur dan unsur lainnya [3]. 


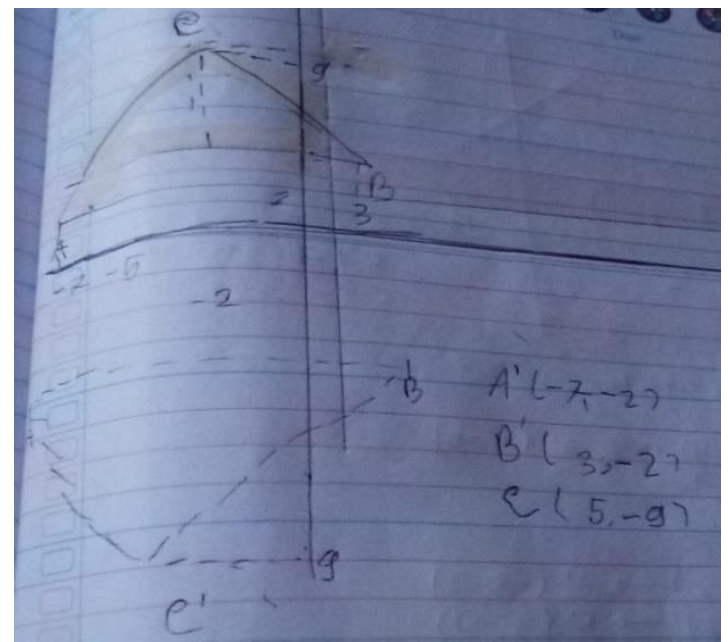

Gambar 1.

Hasil Pekerjaan Siswa Dengan 1 Cara

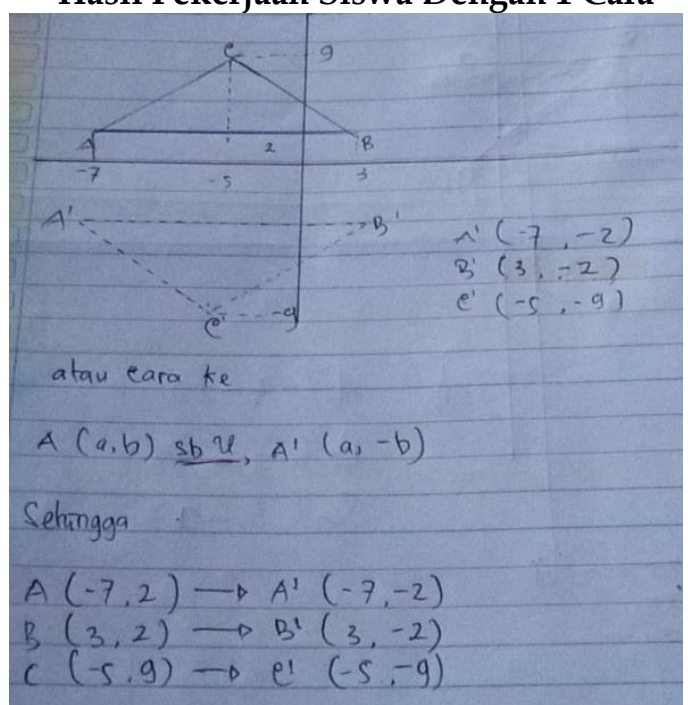

Gambar 2.

Hasil Pekerjaan Siswa Dengan 2 Cara

Kemudian [22] menambahkan bahwa berpikir kritis adalah hobi berpikir yang bisa dikembangkan oleh setiap orang, maka hobi ini harus diajarkan di jenjang pendidikan dasar dan menengah.

Untuk meningkatkan daya berpikir kritis siswa menurut [8] dapat diberikan unsur rangsangan agar siswa semakin giat dalam belajar yaitu dengan membuat sistem evaluasi yang berbeda yang dapat membuka pola pikir siswa semakin luas dan kritis dan membuat pelajaran matematika menjadi menarik tidak menjadi pelajaran yang menakutkan. Dengan itu dituntut untuk lebih kreatif dan inovatif terhadap pembelajaran matematika.

Menurut [9] bahwa generasi milenial butuh pendekatan belajar yang baru. Saat ini dibutuhkan media pembelajaran yang cocok agar siswa mau belajar. Penggunaan media dalam proses pembelajaran bertujuan agar proses pembelajaran dapat berlangsung secara tepat guna dan berdaya guna sehingga mutu pendidikan dapat ditingkatkan. Sebuah game merupakan media hiburan. Game bisa menjadi lebih baik apabila digunakan pemainnya untuk belajar.

Menurut [10] bahwa game dan animasi bisa digunakan untuk membantu meningkatkan visualitas alat peraga matematika sebagai pendukung pendidikan matematika realistik dengan memanfaatkan teknologi informasi. Game-based Learning menjadi salah satu cara memberikan pengalaman pembelajaran yang mampu meningkatkan keikutsertaan kolaborasi siswa dalam pembelajaran. Aplikasi Kahoot sebagai platform teknologi pembelajaran mengkombinasikan pengalaman evaluasi pembelajaran dengan mengkombinasikan melalui game interaktif dan dilengkapi sistem monitoring aktifitas para siswa [11] Inovasi Platfotm Kahoot ini mampu membantu aktifitas evaluasi pembelajaran menjadi menarik, interaktif, kondusif dan mudah dalam memonitaring hasil belajar [14].

Kahoot merupakan platform hasil kolaborasi joint project antara Norwegian University of Technology and Science dengan Johan Brand dan Jamie Brooker sebagai inisiator. Kahoot memiliki dua alamat website https://Kahoot.com/ untuk guru dan https://Kahoot.it/ untuk siswa. Keistimewaan platform ini adalah mengutamakan proses evaluasi 
pembelajaran melalui permainan secara berkelompak walaupun dapat dimainkan secara individu.

Penggunaan software game di komputer maupun aplikasi pada smarthphone didesain untuk menyeimbangkan konten pembelajaran dengan konten permainan serta mampu menilai kemampuan pembelajaran apakah sudah menguasai dan mampu mengaplikasikan pengetahuaanya pada dunia nyata [12].

Digital Game Base Learning memanfaatkan pembelajaran melalui pola belajar dan bermain dengan memanfaatkan perangkat komputer atau smartphone. Melalui metode ini peserta didik distimulasi tiga hal sekaligus yaitu kecerdasan emosi, keceradasan emosional, dan psikomotorik. Pemanfaatan media dan metode Digital Game Base Learning merupakan kombinasi yang sangat dekat dengan kegiatan keseharian peserta didik saat ini yang kita kenal dengan generasi milenial. Serta kecepatan didapatkannya hasil dalam proses evaluasi, guru akan lebih cepat memberikan feedback terhadap hasil evaluasi pembelajaran [13].

\section{METODE PENELITIAN}

Penelitian ini menggunakan Penelitian Tindakan Kelas (PTK). PTK ini bertujuan untuk memperbaiki atau meningkatkan mutu pembelajaran di kelas. Proses penelitian model siklus PTK yang dikembangkan oleh [19] yaitu bahwa setiap siklus terdiri atas : perencanaan (planning), tindakan dan pengamatan (acting \& observing), perefleksian (reflecting) dan perbaikan rencana (revise plan). PTK ini dilaksanakan selama 2 siklus dengan setiap siklus terdiri atas 2 pertemuan. Menurut [15] bahwa PTK cukup 2 siklus asalkan sudah menunjukkan peningkatan hasil belajar atau ketuntasan hasil belajar.

Penelitian dilakukan di MTsN 2 Kota Kediri yang terletak di Jalan Sunan Ampel 12 Ngronggo. Subyek yang menerima tindakan penelitian adalah kelas $9 \mathrm{~J}$ yang terdiri atas 16 putri dan 24 putra, sedangkan subyek pemberi tindakan adalah guru matematika kelas 9J. Pengambilan data pada penelitian ini dengan menggunakan tes kemampuan berpikir kritis dan dokumentasi.

\section{HASIL DAN PEMBAHASAN}

Pada tahap pelaksanaan, peneliti menerapkan pembelajaran sesuai RPP. Sebelum memulai pembelajaran guru memberikan salam, menyampaikan tujuan pembelajaran dan apersepsi. Apersepsi yang dilakukan oleh peneliti yaitu mengaitkan materi transformasi dengan kehidupan sehari-hari. Selanjutnya peneliti memberikan motivasi terlebih dahulu tentang materi yang akan dipelajari. Menurut [7], motivasi dapat menjadi pendorong bagi siswa untuk bersungguh-sungguh dalam proses pembelajaran. Dalam tahap ini, dapat dimaknai bahwa siswa yang termotivasi akan tertarik untuk mengikuti proses pembelajaran sehingga tercapai tujuan pembelajaran.

Pada saat pembelajaran, siswa dibentuk dalam kelompok. Setiap kelompok terdiri dari 4 siswa, sehingga ada 10 kelompok. Setiap kelompok minimal ada satu HP sebagai media dalam mengakses aplikasi kahoot. Guru menampilkan soal kepada semua kelompok dilayar dan membagikan PIN untuk masuk ke link Kahoot. Guru memberikan 6 soal, setiap soal berbeda tingkat kesulitan dan berbeda durasi waktunya, sehingga siswa greget dalam menyelesaikan soal. Guru meminta siswa untuk menyelesaikan soal secara tertulis untuk meminimalisir siswa menjawab secara menebak.

Copyright $(20 \mathrm{xx}$, Jurnal THEOREMS (The Original Research of Mathematics) p-ISSN: 2528-102X, e-ISSN: 2541-4321, URL: http://jurnal.unma.ac.id/index.php/th 
Pembelajaran dengan media kahoot menarik antusias siswa. Hal tersebut nampak ekspresi siswa saat mengetahui hasil jawabannya benar dan posisi peringkat. Sehingga pemakaian kahoot pada pembelajaran tampak lebih hidup dan lebih menyenangkan.

\section{Hasil Siklus 1}

Peneliti mempersiapkan RPP materi transformasi dengan menggunakan media kahoot. Peneliti juga menyiapkan soal yang diberikan ke siswa. Pada gambar 5 di bawah ini contoh soal yang diberikan ke siswa pada akhir siklus 1.

Pada siklus 1 materi yang dipelajari adalah refleksi (pencerminan), pertemuan pertama guru memberikan materi dengan lembar tugas dan memberi contoh penyelesaian beberapa soal. Pada pertemuan kedua peneliti memberikan soal dengan memakai aplikasi kahoot. Diperoleh data pada tabel 1. Pada gambar 7 dan gambar 8 merupakan contoh jawaban tertulis siswa pada siklus 1 .

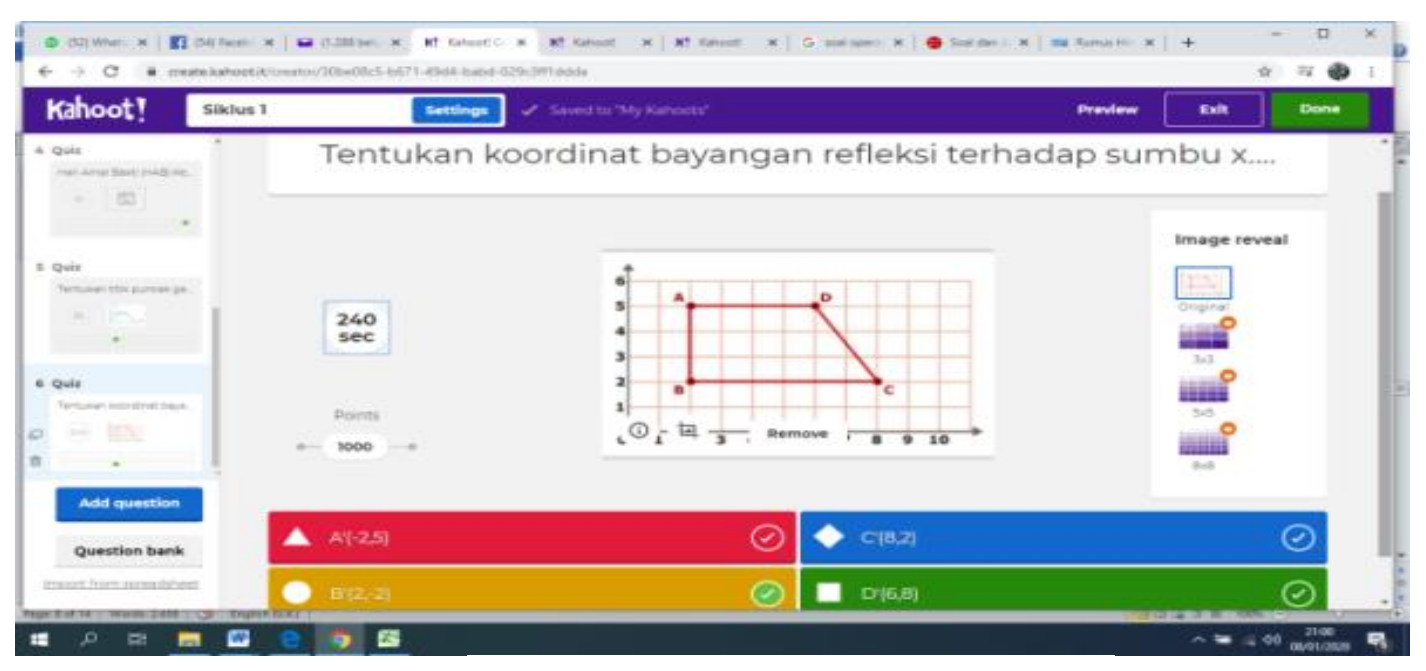

Gambar 5.

Soal Dalam Aplikasi Kahoot

Tabel 1

Data Berpikir Kritis Siswa Pada Siklus 1

\begin{tabular}{|c|l|c|c|}
\hline No & \multicolumn{1}{|c|}{ Indikator Berpikir Kritis } & $\begin{array}{c}\text { Banyak } \\
\text { siswa }\end{array}$ & Prosentase \\
\hline 1. & $\begin{array}{l}\text { Menentukan masalah atau isu nyata, proyek, atau keputusan } \\
\text { yang betul-betul dipertimbangkan untuk dikritisi dengan cara } \\
\text { menuliskan yang diketahui dan ditanyakan }\end{array}$ & 24 & $60 \%$ \\
\hline 2. & $\begin{array}{l}\text { Mencari alternative penyelesaian dengan cara menuliskan } \\
\text { beberapa cara penyelesaian }\end{array}$ & 12 & $30 \%$ \\
\hline 3. & $\begin{array}{l}\text { Membuat alasan yang mendasari dalam fakta-fakta yang } \\
\text { meyakinkan dengan memberikan alasan pada setiap langkah } \\
\text { penyelesaian }\end{array}$ & 28 & $70 \%$ \\
\hline
\end{tabular}


Jurnal THEOREMS (The Original Research of Mathematics) Vol.5 No.1, Juli. hal. 13-24

URL: http://jurnal.unma.ac.id/index.php/th

Naskah masuk:2020-01-17 Naskah diperbaiki:2020-04-16 Naskah diterima:2020-04-19

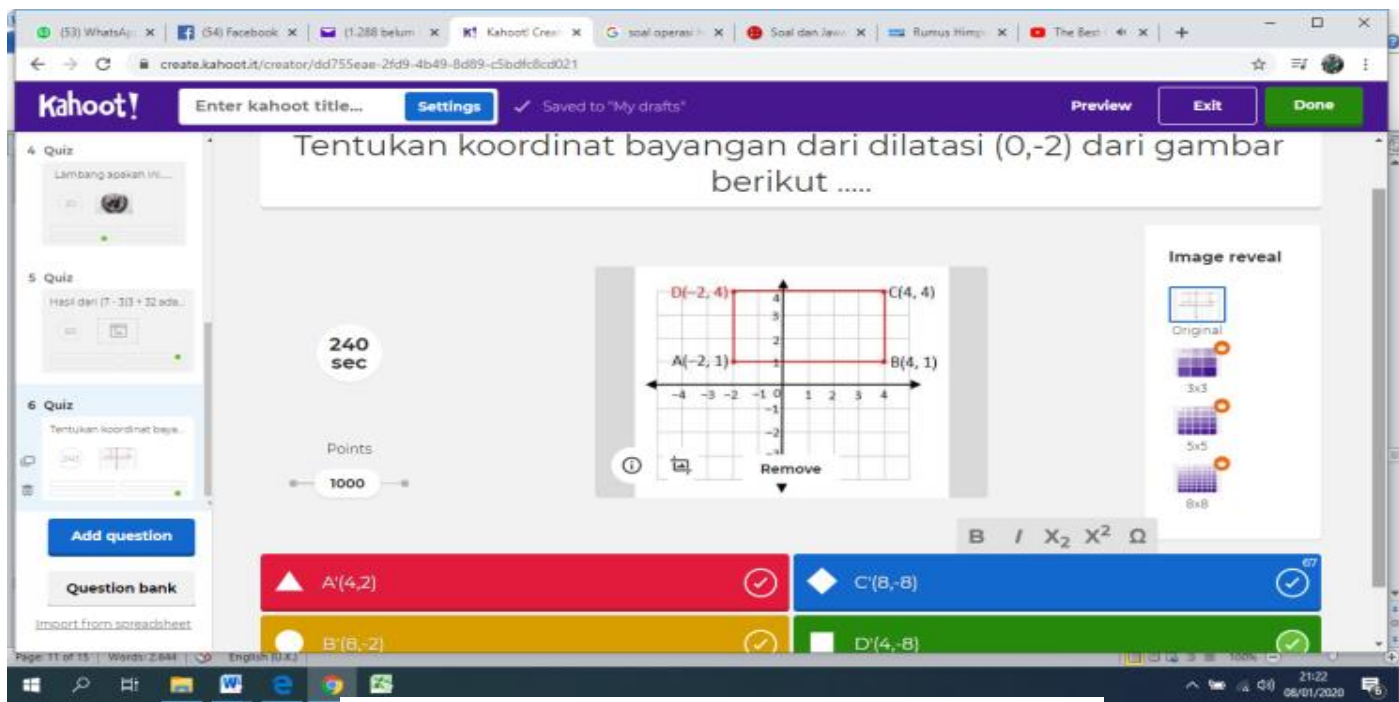

Gambar 6.

Soal Dalam Aplikasi Kahoot Pada Siklus 2

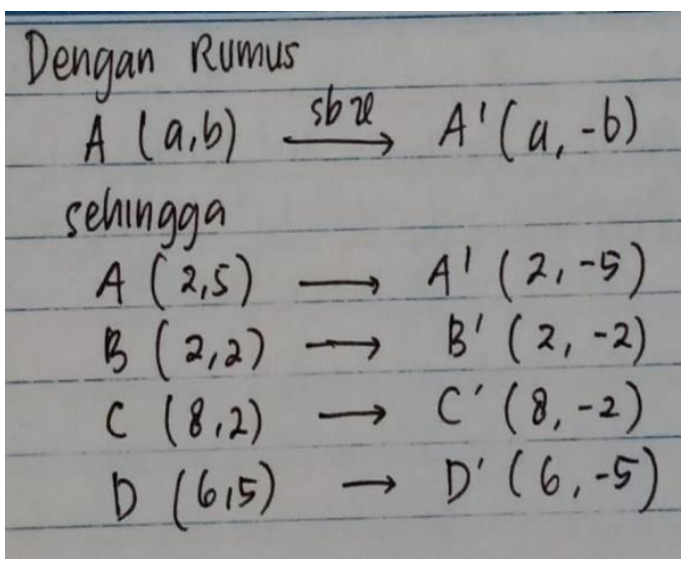

Gambar 7.

Hasil Siklus 1 Dengan 1 Cara

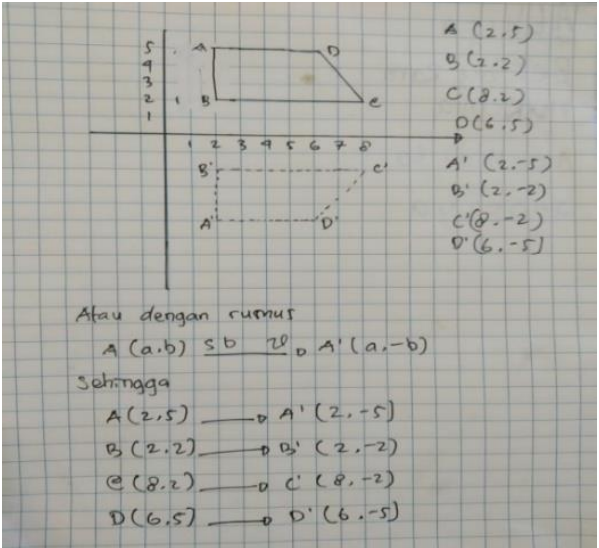

Gambar 8.

Hasil Siklus 1 Dengan 2 Cara

Tabel 2.

Data berpikir kritis siswa Pada Siklus 2

\begin{tabular}{|c|l|c|c|}
\hline No. & \multicolumn{1}{|c|}{ Indikator Berpikir Kritis } & Banyak siswa & Prosentase \\
\hline 1. & $\begin{array}{l}\text { Menentukan masalah atau isu nyata, proyek, atau } \\
\text { keputusan yang betul-betul dipertimbangkan untuk } \\
\text { dikritisi dengan cara menuliskan yang diketahui dan } \\
\text { ditanyakan. }\end{array}$ & 28 & $70 \%$ \\
\hline 2. & $\begin{array}{l}\text { Mencari alternative penyelesaian dengan cara } \\
\text { menuliskan beberapa cara penyelesaian }\end{array}$ & 20 & $80 \%$ \\
\hline 3, & $\begin{array}{l}\text { Membuat alasan yang mendasari dalam fakta-fakta } \\
\text { yang meyakinkan dengan memberikan alasan pada } \\
\text { setiap langkah penyelesaian }\end{array}$ & 32 & $80 \%$ \\
\hline
\end{tabular}


Jurnal THEOREMS (The Original Research of Mathematics) Vol.5 No.1, Juli. hal. 13-24

URL: http://jurnal.unma.ac.id/index.php/th

Naskah masuk:2020-01-17 Naskah diperbaiki:2020-04-16 Naskah diterima:2020-04-19

Tabel 3

Peningkatan Kemampuan Berpikir Kritis Siswa

\begin{tabular}{|c|l|c|c|c|}
\hline No. & \multicolumn{1}{|c|}{ Indikator Berpikir Kritis } & $\begin{array}{c}\text { Sebelum ada } \\
\text { Perlakuan }\end{array}$ & $\begin{array}{c}\text { Siklus } \\
\mathbf{1}\end{array}$ & $\begin{array}{c}\text { Siklus } \\
\mathbf{2}\end{array}$ \\
\hline 1. & $\begin{array}{l}\text { Menentukan masalah atau isu nyata, proyek, atau } \\
\text { keputusan yang betul-betul dipertimbangkan } \\
\text { untuk dikritisi dengan cara menuliskan yang } \\
\text { diketahui dan ditanyakan }\end{array}$ & $40 \%$ & $60 \%$ & $70 \%$ \\
\hline 2. & $\begin{array}{l}\text { Mencari alternative penyelesaian dengan cara } \\
\text { menuliskan beberapa cara penyelesaian }\end{array}$ & $20 \%$ & $30 \%$ & $50 \%$ \\
\hline 3. & $\begin{array}{l}\text { Membuat alasan yang mendasari dalam fakta- } \\
\text { fakta yang meyakinkan dengan memberikan } \\
\text { alasan pada setiap langkah penyelesaian }\end{array}$ & $50 \%$ & $70 \%$ & $80 \%$ \\
\hline
\end{tabular}

Penyelesaian oleh siswa yang tergolong kategori rendah dapat dilihat pada gambar 6 dimana siswa menyelesaikan masalah walapun hasilnya benar namun kurang rapi dan hanya dengan 1 cara penyelesaian. Sedangkan hasil pekerjaan siswa yang tergolong kategori baik dapat dilihat pada gambar 7 . Hasil pekerjaan rapi dan penyelesaian dengan 2 cara.

Dari tabel 1 dan hasil pekerjaan siswa di gambar 6 dan 7 menunjukkan bahwa dengan pemakaian media kahoot sudah terdapat peningkatan kemampuan berpikir kritis siswa dibandingkan sebelumnya yang tanpa pemakaian media kahoot. Pada indikator 1 terdapat peningkatan 20\%, pada indikator 2 terdapat peningkatan sebesar $10 \%$ dan pada indikator 3 terdapat peningkatan sebesar $20 \%$.

Melalui media kahoot ini pembelajaran hal yang bersifat abstrak bisa menjadi konkrit dan menantang. Setelah melihat hasil siklus 1 ini tim peneliti melakukan refleksi dengan melihat kegiatan mulai dari awal. Untuk planning (perencaan), perlu ada suntikan motivasi yang lebih di awal pembelajaran, karena antusias siswa belum seperti yang diharapkan. Untuk action (tindakan) perlu diubah pembagian kelompoknya, yaitu dengan memisahkan beberapa anak yang kurang aktif berada pada kelompok yang sama sehingga persebaran anak yang aktif lebih merata dan bisa menjadi tutor sebaya.

\section{Hasil Siklus 2}

Siklus 2 peneliti memberikan motivasi lebih kepada siswa karena mempertimbangkan hasil evaluasi dan refleksi siklus 1 untuk mencapai target prosentasi penelitian. Selanjutnya merombak pembagian kelompok agar terjadi penyebaran anak-anak yang aktif di beberapa kelompok sehingga bisa menjadi tutor sebaya di kelompoknya yang baru. Sebagaimana menurut Vigotsky (dalam Faizi, 2013) mengemukakan bahwa pembagian kelompok perlu memperhatikan siswa yang dianggap mempunyai kemampuan lebih dibandingkan teman kelompoknya sehingga tutorial di kelompok berjalan dengan baik.

Materi yang di bahas yaitu dilatasi. Pertemuan pertama guru memberikan materi dengan lembar tugas dan memberi contoh penyelesaian beberapa soal. Pada pertemuan kedua peneliti memberikan soal dengan memakai aplikasi kahoot.

Pada gambar 6 adalah contoh soal yang diberikan ke siswa pada siklus 2, 
dan tabel 2 adalah data berpikir kritis siswa pada siklus 2. Untuk gambar 9 dan gambar 10 adalah contoh jawaban tertulis siswa pada siklus 2 .

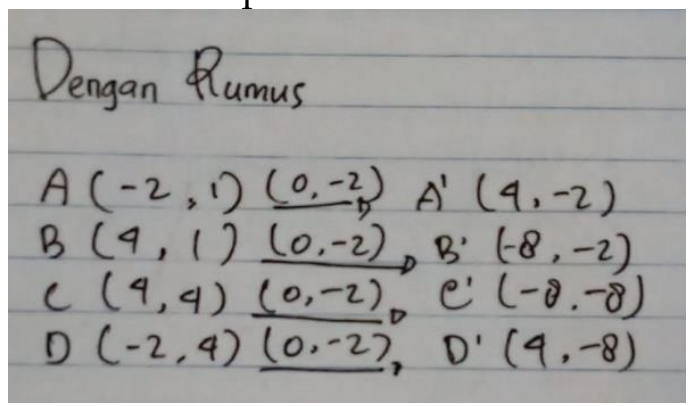

Gambar 9.

Hasil Siklus 2 Dengan 1 Cara

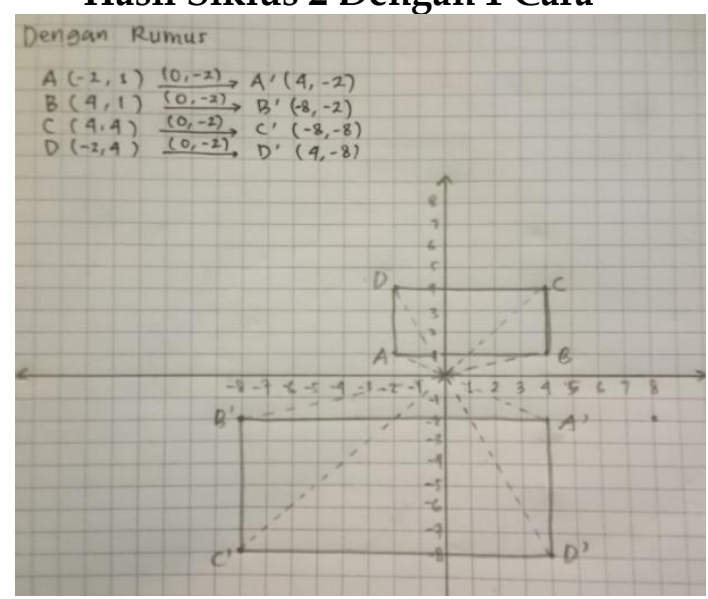

Gambar 10.

Hasil Siklus 2 Dengan 2 Cara

Dari hasil siklus 2 ini terdapat peningkatan kemampuan berpikir kritis siswa dibandingkan dengan perlakuan sebelumnya seperti tampak pada tabel 2. Hal ini menunjukkan perbaikan perlakuan pada siklus 2 ini mempunyai pengaruh seperti yang diharapkan, yaitu peningkatan kemampuan berpikir kritis siswa. Menurut [4] pemberian motivasi sebelum kegiatan pembelajaran dan pembentukan kelompok secara benar sesuai dengan kaidah cukup berpengaruh terhadap hasil pembelajaran.

Pemakaian media kahoot tanpa ada perlakuan yang memadai seperti pada siklus 1 menghasilkan pembelajaran yang kurang diharapkan seperti tampak pada tabel 1. Oleh karena itu pemakaian media kahoot perlu juga diimbangi pemberian motivasi dan pembagian kelompok yang tepat agar menghasilkan pembelajaran yang diharapkan seperti tampak pada tabel 2 pada siklus 2. Hal ini menunjukkan bahwa pemakain media kahoot tidak serta merta langsung bisa meningkatkan kemampuan berpikir kritis siswa, tetap membutuhkan kepedulian guru pengajar untuk memberikan motivasi pembelajaran.

\section{Diagram Prosentase Capaian indikator}

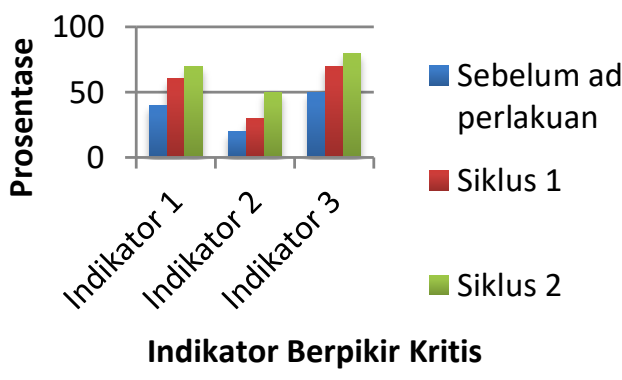

\section{Gambar 11.}

Diagram Peningkatan Setiap Indikator

Gambar 11 dan tabel 3 terlihat bahwa terdapat peningkatan kemampuan berpikir kritis siswa mulai dari sebelum ada perlakuan, siklus 1 dan siklus 2. Peningkatan ini tidak semata oleh pemakaian media kahoot saja namun ada pemberian motivasi dan pembentukan kelompok juga mempunyai pengaruh terhadap hasil pembelajaran.

Pada indikator 1, terdapat peningkatan kemampuan. Kondisi ini dapat dimaknai bahwa terdapat peningkatan kemampuan siswa menentukan masalah dengan keputusan yang betul-betul dipertimbangkan untuk dikritisi.

Pada indikator 2, mengalami peningkatan. Kondisi ini dapat dimaknai bahwa terdapat peningkatan kemampuan siswa mencari alternatif 
penyelesaian dengan cara menuliskan beberapa cara penyelesaian.

Pada indikator 3, mengalami peningkatan. Kondisi ini dapat dimaknai bahwa terdapat peningkatan kemampuan siswa membuat alasan yang mendasari dalam fakta-fakta yang meyakinkan dengan memberikan alasan pada setiap langkah penyelesaiannya.

Pada gambar 11 menunjukkan bahwa terdapat kenaikan pada setiap indikator proses berpikir kritis sehingga ada peningkatan kemampuan berpikir kritis siswa dengan media kahoot pada materi transformasi. Sejalan dengan penelitian ini bahwa menurut [5] menyatakan bahwa, peningkatan penggunaan teknologi dalam berbagai aspek kehidupan merupakan karakteristik umum generasi Z. Selain untuk meningkatkan motivasi belajar serta efektivitas pembelajaran, namun juga untuk memfasilitasi kemampuan berpikir kritis siswa. Dengan demikian pemanfaatan aplikasi kahoot dapat meningkatkan daya berpikir kritis siswa.

Demikian juga menurut [6] menyatakan bahwa pembelajaran berbasis teknologi informasi dapat meningkatkan keterampilan berpikir kritis siswa. Oleh karena itu pemanfaatan teknologi informasi termasuk juga pemakaian aplikasi kahoot dapat meningkatkan daya berpikir kritis siswa.

\section{KESIMPULAN}

Kahoot sebagai media pembelajara berbasis digital game based learning dapat dioptimalkan untuk meningkatkan kemampuan berpikir kritis siswa. Namun demikian untuk memaksimalkan hasil pembelajaran perlu pemberian motivasi kepada siswa sebelum pembelajaran serta pembagian kelompok harus sesuai kaidah.

\section{SARAN}

Perlu ada penelitian lebih lanjut untuk indikator - indikator berpikir kritis yang lain agar lebih menyakinkan peranan aplikasi kahoot terhadap kemampuan berpikir kritis siswa.

\section{DAFTAR PUSTAKA}

[1] Krulik, s dan Rudnick, J.A (1993). The New Sourcebook for Teaching Reasoning and problem Solving in Elementer School. Massachusetts: Allyn \& Bacon A Simon \& Schuster Company:

[2] Setiawan. (2005). Model Pembelajaran dengan Pendekatan NHT. Tersedia online https:/ / bagawanabiyasa.wordpres s.com/2013/05/02/kemampuanberpikir-kritis/ diakses tanggal 12 Desember 2019: ...

[3] Maulana. (2008). "Pendekatan Metakognitif Sebagai Alternatif Pembelajaran Metematika Untuk Meningkatkan Kemampuan Berpikir Kritis Siswa PGSD". Jurnal Pendidikan Dasar. (10). 39-46: ...

[4] Gunawan dan Darmani, 2018, "Model dan Strategi Pembelajaran Aktif dan Menyenangkan". Nizamia Learning Center, Surabaya.

[5] Nisa, Setyosari, Sulthoni, 2017, "Pemanfaatan Teknologi Informasi Untuk Memfasilitasi Kemampuan Berpikir Kritis Peserta Didik". Jurnal Prosiding TEP \& PDs Transformasi Pendidikan Abad 21, hal 22-26.

[6] Widhiyanti (2007) "Pembelajaran Berbasis Teknologi Informasi Untuk Meningkatkan Pemahaman Konsep Dan Keterampilan Berpikir Kritis Siswa Pada Topik Sifat Koligatif Larutan". Artikel Program 
Jurnal THEOREMS (The Original Research of Mathematics) Vol.5 No.1, Juli. hal. 13-24

URL: http://jurnal.unma.ac.id/index.php/th

Naskah masuk:2020-01-17 Naskah diperbaiki:2020-04-16 Naskah diterima:2020-04-19

Pascasarjana Universitas

Pendidikan Indonesia.

[7] Riadi, (2013), Motivasi Belajar, https:/ / www.kajianpustaka.com/

2013/04/motivasi-belajar.html diakses 10 Desember 2019

[8] Amalia, Raula Samsul,. Noor Aini Habibah, dan Arif Widiyanto "Pengembangan Alat Evaluasi Kemampuan Berpikir Kritis Siswa pada Pembelajaran IPA Terpadu Model Webbed Tema Lingkungan." Unnes Science Education Journal 3, no. 2 (2014).

[9] Itqan, Moh Syadidul (2018) "Pendekatan Game Android Untuk Meningkatkan Minat Belajar Matematika Siswa Sekolah Dasar," EduMatSains 2, no. 2 (2018): 161170.

[10]Dadang Sudrajat and Tifan Muslim, (2012). "Perancangan Aplikasi Game Aritmatika Pada Handphone Untuk Melatih Kemampuan Berhitung Kelas 1 Dan 2 Sekolah Dasar Negeri II Ciperna Kabupaten," JURNAL ICT 7, no. 1 (2012).

[11] M. Correia and R. Santos (2017) "Game Based Learning: The Use of Kahoot in teacher education". 2017 International Symposium on Komputer in Education (SIIE), Lisbon, 2017, pp. 1- 4, doi: 10.1109/SIIE.2017.8259670

[12]Ervan, Muhammad. (2017) Meningkatkan Minat dan Hasil Belajar Mahasiswa Pada Perkuliahan Elektronika Dasar Melalui Digital Game Base Learning. Prosiding Seminar Nasional Pendidikan dan Pengembangan Pendidikan Indonesia. ISSN 2598-1978

[13] Wihanry, Indra (2017) Perancangan Aplikasi Pembelajaran Akasara lontar Dengan Metode Game Based
Learning. Diunduh dari http://tematika.uajm.ac.id/index .php/ tematika/article /viewfile /40/31 Indonesia

[14] Dewi, KC. (2018) Pengembangan alat evaluasi menggunakan Aplikasi Kahoot pada pembelajaran Matematika Kelas X. Diundah dari http:/ / repository.radenintan.ac.id /4286/1/Skripsi Cahya Kurnia.pdf

[15] Muslich, Masnur (2009), "Peneltitian Tindakan Kelas Menuju Profesionalitas Guru Demi Ketercapaian Maksimal Siswa", diakses melalui : http://ptkmasnur-muslich.blogspot.com /2009/10/jumlah-siklus-dan-jenisevaluasi-dalam.html

[16] Susilo, Djoko , (2004) Perancangan dan Implementasi Komponen Visual Delphi.

[17]Hadi, A.M. (2007). Pengaruh Pembalajaran Problem Based Learning (PBL) terhadap Kemampuan Berpikir Kritis dan Pemahaman Konsep Biologi Siswa SMA Negeri di Kota Malang. Skripsi. Tidak Diterbitkan. Malang: Universitas Negeri Malang.

[18]Corebima, A.D., 2007, Pembelajaran Biologi Yang Memberdayakan Kemampuan Berpikir. (Makalah disajikan pada pelatihan Guru guru di Sulawesi Utara. 21 Januari)

[19] Kemmis,S \& Mc.Taggart,R (1990). The Action Research Planner. Victoria : The Deakin University.

[20]Pott,B. (1994). Strategies for Teaching Critical Thinking. Practical Assessment, Research \& Evaluation, 4(3), p 293-31

[21] Lie, 2004. Metode Pembelajaran. Yogyakarta: Rieneka Cipta

[22] Johnson, E.B. (2007). Contextual Teaching and Learning. California : Corwin Press,Inc

Copyright $(20 \mathrm{xx}$, Jurnal THEOREMS (The Original Research of Mathematics) p-ISSN: 2528-102X, e-ISSN: 2541-4321, URL: http://jurnal.unma.ac.id/index.php/th 